\title{
IN VITRO ESTABLISHMENT AND PROPAGATION OF A BRAZILIAN STRAIN OF ANAPLASMA MARGINALE WITH APPENDAGE IN IDE8 (IXODES SCAPULARIS) CELLS
}

\author{
Camila V. Bastos $^{1}$; Lygia M. F. Passos²*; Maria Mercês C. Vasconcelos ${ }^{1}$; Múcio F. B. Ribeiro ${ }^{1}$
}

${ }^{1}$ Departamento de Parasitologia, Universidade Federal de Minas Gerais, Belo Horizonte, MG, Brasil; ${ }^{2}$ Departamento de Medicina Veterinária Preventiva, Escola de Veterinária, Universidade Federal de Minas Gerais, Belo Horizonte, MG, Brasil

Submitted: March 10, 2008; Returned to authors for corrections: April 22, 2008; Approved: March 13, 2009.

\begin{abstract}
A Brazilian isolate of Anaplasma marginale with appendage was successfully established and maintained in vitro in a tick cell line (IDE8). Infection was confirmed by optical and transmission electron microscopy. In addition, primers MSP1aNF2 and MSP1aNR2 amplified products from DNA extracted from infected IDE8 cells. Comparisons with partial sequences of the mspl $\alpha$ gene and the complete genome of A. marginale confirmed that the sequences of amplified fragments were from the $A$. marginale genome. This is the first establishment of a Brazilian A. marginale isolate in tick cells, representing a new system for biological and molecular studies and also a new source of material for diagnosis and development of vaccines.
\end{abstract}

Key words: IDE8 cells, Anaplasma marginale, in vitro culture

\section{INTRODUCTION}

Bovine anaplasmosis, caused by the intraerytrocitic rickettsia Anaplasma marginale, is a tick transmitted disease characterized by anemia, weight loss, fever, abortion and deaths, and can lead to significant economical losses for the dairy and meat industry (22). Calves are less susceptible than adults to A. marginale infections and when infected, usually present moderate clinical signals. Animals that are able to recover from an acute phase undergo a persistent infection status characterized by cyclical and low rickettsemias $(10,16)$. These animals, so called carriers, become immune and resistant to new clinical diseases in case of exposure to a homologous strain (19). However, they act as a source of infection for other animals within the herd or the area.

Differences among A. marginale strains have been described on the basis of morphology $(8,11,18)$, tick transmission $(20,23)$, virulence (13), membrane surface proteins (MSP) (1), and reactivity detected by monoclonal antibodies (21).

Ribeiro et al. (18) reported the first ultra-structural description of a Brazilian isolate of $A$. marginale with an inclusion appendage, obtained from an acutely infected cow from Pará de Minas, Minas Gerais. Later, this isolate was characterized by a panel of monoclonal antibodies that revealed antigenic differences among Brazilian isolates (8). Furthermore, this isolate with appendage was not infective for Boophilus microplus ticks (9).

The IDE8 line had been established from embryonic Ixodes scapularis ticks (14) and recently we have reported efficient ways to preserve this cell line by refrigeration and cryopreservation (3). Few other isolates of $A$. marginale have been established in vitro in IDE8 cells $(4,5,15,24)$. However, no Brazilian strains of $A$. marginale have been previously establishment in vitro using tick cell systems.

Thus, the present paper reports the first establishment of a strain of A. marginale with appendage in IDE8 cells, its morphological characterization through optical and electronic microscopy, as well as the sequence of the mspla gene during its in vitro cultivation in this tick cell line.

\section{MATERIALS AND METHODS}

One Friesian calf, free from hemoparasites, was used to provide infected blood for in vitro infections. The calf had been

*Corresponding Author. Mailing address: Departamento de Medicina Veterinária Preventiva, Escola de Veterinária, Universidade Federal de Minas Gerais, Caixa Postal 567, CEP 30123-970, Belo Horizonte, Minas Gerais, Brasil. E-mail: lygia@vet.ufmg.br 
separated from his mother before ingestion of colostrum and was housed in an individual pen protected against ticks and flies. The animal was fed with powered milk, commercial ration and water ad libitium. Weekly, the calf and the animal shed were treated with cypermethrin acaricide and the calf was monitored through examination of Giemsa stained blood smears to ensure the absence of any hemoparasite infection. Serum samples were also examined by the indirect fluorescent antibodies test (IFAT) for detection of anti- $A$. marginale, antiBabesia bovis and B. bigemina antibodies. Once the calf was ensured to be free from hemoparasitic infections, it was splenectomized and inoculated intravenously with $5 \times 10^{7}$ infected erythrocytes of an isolate of $A$. marginale with appendage (18) (GenBank accession number EU676176), which had been kept as a frozen stabilate in liquid nitrogen. When rickettsemia in blood smears reached 64\% (37 days post inoculation), blood samples were collected with EDTA and were processed as described by Blouin et al. (5). The material was aliquoted into $1.8 \mathrm{~mL}$ vials, which were cryopreserved in liquid nitrogen using DMSO (6\%) as cryoprotectant; these cryostabilates were used to infect the IDE8 cells.

IDE8 cells were cultured in L-15B supplemented with foetal calf serum in $25 \mathrm{~cm}^{2}$ flasks, following standard procedures (14). Each of two flasks containing on growing monolayers of IDE8 cells were infected with one A. marginale cryostabilate. After a quickly defrosting procedure (immersion into a $37^{\circ} \mathrm{C}$ water bath), the content of each vial was centrifuged at $10,000 \times \mathrm{g}$, for 20 minutes and the sediment was ressuspended in $5 \mathrm{~mL}$ of medium L-15B containing inactivated $5 \%$ fetal calf serum. In order to make the medium more appropriate for anaplasma growth, $\mathrm{NaHCO}_{3}(2.5 \mathrm{~g} / \mathrm{L})$ and MOPS $(2.093 \mathrm{~g} / \mathrm{L})$ were added to the complete medium (15). The inoculated flasks were incubated at $34^{\circ} \mathrm{C}$ and the first medium change was carried out at 24 hours after inoculation; the subsequent medium changes were done weekly. The cultures were monitored daily through examination under an inverted microscope with phase contrast.

At each weekly medium change, samples from the supernatants were used to make cytospin smears, which were stained with Giemsa and examined in a light microscopy under oil immersion.

From cultures exhibiting growth of $A$. marginale, $1 \mathrm{~mL}$ of cell suspensions was collected, centrifuged at 10,000 $\mathrm{x} g$ for 10 minutes at $4^{\circ} \mathrm{C}$ and the pelleted cells, obtained after supernatant removal, were fixed in $2.5 \%$ glutaraldehyde in sodium cacodylate buffer (0.2M, pH 7.2), during 24 hours at $4^{\circ} \mathrm{C}(17)$. IDE8 cells were then washed three times in cacodylate buffer, included in $2 \%$ Agar and post-fixed in a solution containing $2 \%$ osmium tetroxide in sodium cacodylate buffer $(0.2 \mathrm{M}, \mathrm{pH}$ 7.2) at $4^{\circ} \mathrm{C}$ during two hours. The agar blocks were washed in cacodylate buffer and were dehydrated in increasing concentrations of ethylic alcohol for posterior inclusion in EponAraldite. Ultra-thin sections (90 nm) were stained with uranyl acetate and lead citrate and were examined in a transmission electron microscopy (Zeiss EM-10).

DNA was extracted from samples of infected and uninfected IDE8 cells, using a commercial kit (Wizard ${ }^{\circledR}$ Genomic DNA Purification, PROMEGA), following the manufacturer instructions for extraction from cells and tissues. The $m s p l \alpha$ gene of $A$. marginale was amplified from the DNA through PCR using 20pmol of each primer, MSP1aNF2 (5 - CAC CGC CAA ACA TGAAGT CGACAA - $3^{\circ}$ ) and MSP1aNR2 (5'- TGT GGT TGT CCT CTT TCC CGA TGT - $3^{\circ}$ ), in a final volume of $50 \mu \mathrm{l}$ [0.2 mM dNTP, $5 \mu \mathrm{l}$ DNA Polimerase Taq (1x), $0.5 \mu \mathrm{l}$ DNA Polimerase Taq (2.5U) and ultrapure sterile water to complete the final volume]. The reactions were processed adding $5 \mu \mathrm{l}$ of each extracted DNA in an automatic thermocycling reactor (Eppendorf Mastercycler ${ }^{\circledR}$ ) with 35 cycles. After the initial denaturation of 5 minutes at $94^{\circ} \mathrm{C}$, each cycle lasted 30 seconds of denaturation at $94^{\circ} \mathrm{C}$, one minute annealing at $60^{\circ} \mathrm{C}$ and one minute and 30 seconds extension at $72^{\circ} \mathrm{C}$. The final step was 5 minutes at $72^{\circ} \mathrm{C}$ and maintenance of samples at $18^{\circ} \mathrm{C}$. The PCR products were submitted to electrophoresis in $1 \%$ agarose gels, which were stained with ethidium bromide for detection of amplified fragments.

PCR products from infected IDE8 cells were purified, following recommendations in the GFX PCR DNA kit (GE Healthcare Biosciences). The purified DNA was sequenced using the MSP1a primers, as previously described, and this was followed by the precipitation of unincorporated nucleotides.

The products from sequencing were read in an automatic capillary MegaBACE 1000 sequencing system and sequences were aligned and edited using the MEGA 3.0 program (12). To confirm identity, the sequence was compared with that available in the GenBank (http://www.ncbi.nlm.nih.gov), accession numberEU676176.

\section{RESULTS}

A. marginale infected IDE8 cells were first observed on day 8 after inoculation, as small and compact colonies, which were intensively stained in the cytoplasm of IDE8 cells (Fig. 1A). In the following days distinct forms of colonies were observed, suggesting an evolutive sequence. Initially, well defined parasitophorous vacuoles containing compact colonies were formed (Fig. 1B). In the subsequent stage, the corpuscles were clearly isolated (Fig. 1C), with increasing numbers (Fig. 1D). On day 12 after inoculation, large colonies were observed, and their corpuscles were released into the culture medium after disruption of the vacuole membrane (Fig. 1E and 1F). A. marginale cultivation was propagated continuously along 18 months with several passages, which were carried out when approximately $30 \%$ of the cells were infected.

The images obtained from transmission electron microscopic analysis confirmed the $A$. marginale infection in IDE8 cells. 

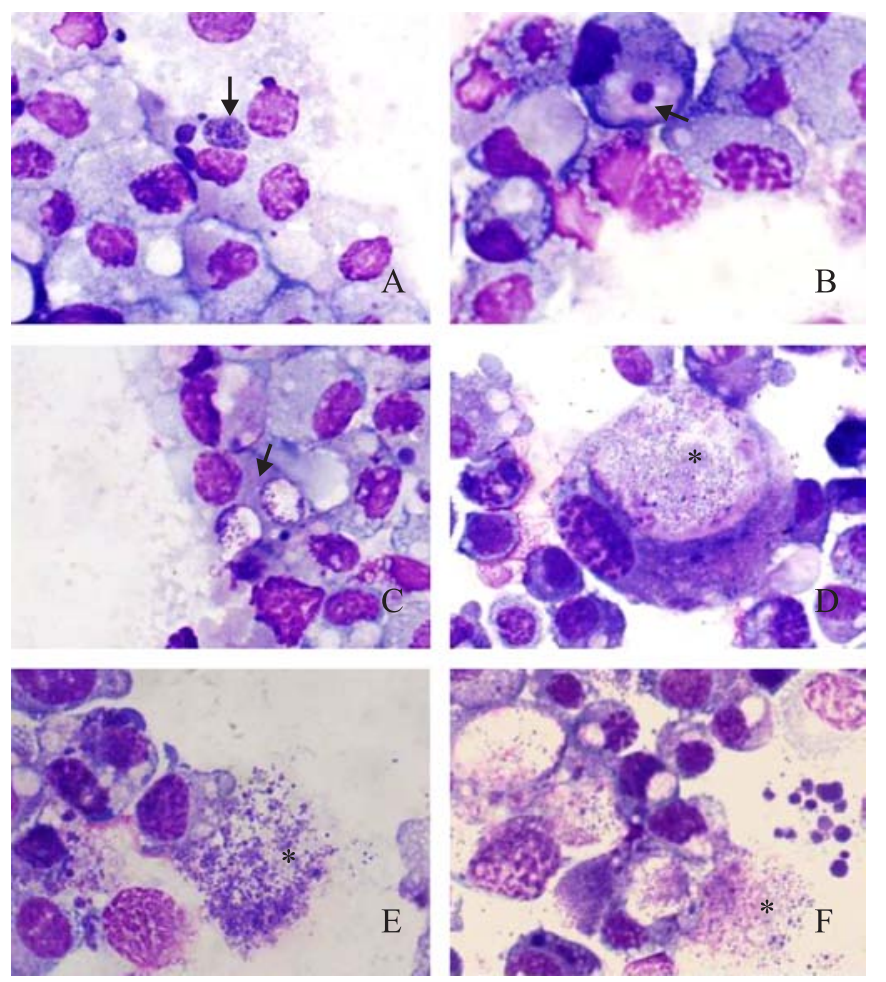

Figure 1. IDE8 cells infected with Anaplasma marginale with appendage. (A) Formation of vacuoles containing $A$. marginale (arrow); (B) Initial formation of A. marginale colonies (arrow); (C) Colonies with isolated corpuscles (arrow); (D) Large colony of $A$. marginale with dislocation of the nucleus (asterisk); (E) Rupture of a colony releasing corpuscles (asterisk); (F) $A$. marginale extra cellular corpuscles (asterisk).

Due to the large quantity of initial corpuscles present in the inoculum, some IDE8 cells were invaded by several corpuscles. The corpuscles were adhered to the cell membrane (Fig. 2A), which showed later a depression (Fig. 2B). After entering, the corpuscles were seen inside parasitophorous vacuoles, and some of them were undergoing binary division (Fig. 2B). Several colonies were seen within a cell (Fig. 2B and C). Thereafter, large colonies were observed, in general one in each IDE8 cell, although some cells had multiple colonies (Fig. 2C). Several initial bodies were observed free in the culture medium, as dense forms (Fig. 2D).

Primers MSP1aNF2 and MSP1aNR2 amplified products from DNA extracted from $A$. marginale infected IDE8 cells, while no amplification was detected from uninfected IDE8 cells. The sequencing analysis revelead a fragment of 1166 nucleotides that where identical to the original sequence (GenBank accession number EU676176). Therefore, the $m s p 1 \alpha$ gene found in the original inoculum was conserved in infected cultured IDE8 cells.
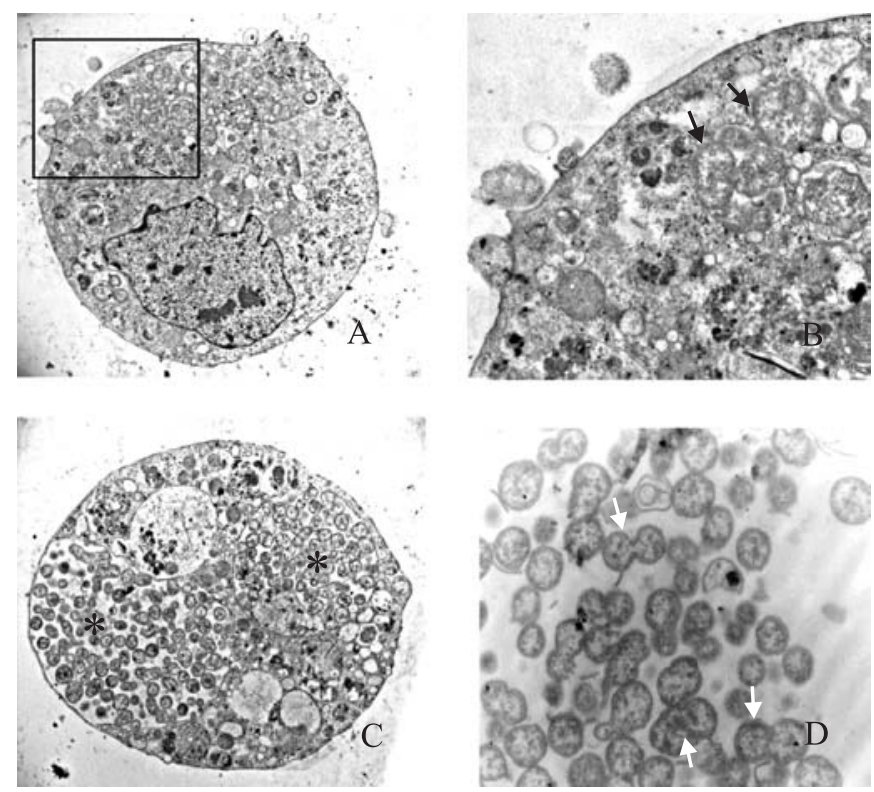

Figure 2. Electron micrograph of IDE8 cells infected with Anaplasma marginale with appendage. (A) Adhesion of a dense form of $A$. marginale on the membrane of the IDE8 cell, initiating cellular invasion; (B) Depression of the cytoplasmatic membrane of the IDE8 cell; (C) IDE8 cell containing two intracytoplasmatic colonies with several corpuscles of $A$. marginale. The colonies occupy most of the cytoplasm of the cell (asterisks); (D) Dense forms of $A$. marginale free in the extra cellular medium, able to infect new cells (arrows).

\section{DISCUSSION}

This in vitro culture system for $A$. marginale using tick cells opens new perspectives to the study of bovine anaplasmosis, particularly in areas where the infection is endemic and the maintenance of bovine donors free from hemoparasites is difficult and expensive. The present work constitutes the first establishment in vitro of a Brazilian rickettsia using tick cells.

The process of colony formation followed the same pattern described by Blouin and Kocan (4) and the sequence of pictures showed here is of relevance for researchers who are initiating to culture this rickettsia in vitro. The electron microscopy analysis revealed a penetration process of initial corpuscles into IDE8 cells similar to that described by Blouin et al. (5). The multiple infection of cells with several vacuoles being formed in the cytoplasm of IDE8 cells suggest a fusion of vacuoles, forming large colonies, as observed in later stages.

Gonçalves-Ruiz et al. (9) demonstrated, through transmission electron microscopy, that this isolate with appendage has no developmental stages into epithelial gut cells of engorged $B$. microplus females that had been fed on calves undergoing high 
rickettsemia. In addition, no transestadial or intrastradial transmissions were observed. For these reasons, this isolate was considered to be non infective for B. microplus ticks, suggesting mechanical transmissions to be the main way for its maintenance in nature.

On the other hand, Blouin et al. (6) indicated that $A$. marginale isolates that are not tick-transmitted are not able to grow in tick cell cultures, and therefore propagation of these isolates in vitro would not be possible. However, this was not the case for this particular isolate, which is not transmissible by ticks and nevertheless could be successfully established in the in vitro IDE8 cells. Thus, this in vitro culture system can be very useful as a new tool to evaluate the development of different stages of Anaplasma strains, as well as their relationship within the tick cells.

It has also been proved that cultured A. marginale strains retain their antigenic composition and infectivity for cattle after successive passages $(2,4,15)$. The mspl $\alpha$ gene is genetically stable, as it does not change during tick and animal passage or in vitro culture of an isolate (2).

The sequence of the $m s p l \alpha$ gen obtained from the $A$. marginale with appendage after cultivation was highly preserved when compared to the original sequence obtained from the donor blood. Thus, it was proved that the MSP1a protein was conserved in this Brazilian isolate after in vitro cultivation in tick cells. Similarly, Bowie et al. (7) reported that the mspl $\alpha$ sequence of an Oklahoma isolate of $A$. marginale did not change after successive passages in vitro or after being transmitted through Dermacentor variabilis. Therefore, this in vitro culture system constitute a new tool to study Brazilian strains of A. marginale, providing a new source of this rickettsia for in vitro studies, diagnostic tests and for the development of vaccines.

\section{ACKNOWLEDGEMENTS}

The authors thank FAPEMIG for the financial support (grant EDT 2198/03), CNPq and CAPES for awarding scholarships, and Dr U.G. Munderloh (University of Minnesota, USA) for permission to use the IDE8 cell line.

\section{RESUMO}

\section{Estabelecimento e propagação in vitro de uma amostra brasileira de Anaplasma marginale com apêndice em células IDE8 (Ixodes scapularis)}

Uma amostra brasileira de Anaplasma marginale com apêndice foi estabelecida e mantida in vitro em uma linhagem de células de carrapatos (IDE8). A infecção foi confirmada através de microscopia ótica e eletrônica de transmissão. Além disso, os primers MSP1aNF2 e MSP1aNR2 amplificaram produtos do
DNA extraído das células infectadas. Comparações de sequências parciais do gene $m s p l \alpha$ e do genoma completo de A. marginale confirmaram que as sequências dos fragmentos amplificados pertenciam ao genoma de A. marginale. Este é o primeiro estabelecimento in vitro de uma amostra brasileira de A. marginale em células de carrapatos, representando um novo sistema para estudos biológicos e moleculares, além de ser uma nova fonte de material para o desenvolvimento de testes diagnósticos e de vacinas.

Palavras-chave: IDE8 cells, Anaplasma marginale, cultivo in vitro

\section{REFERENCES}

1. Allred, D.R.; McGuireo, T.C.; Palmer, G.H.; Leibt, S.R.; Harkins, T.M.; McElwain, T.F.; Barbet, A.F. (1990). Molecular basis for surface antigen size polymorphisms and conservation of a neutralizationsensitive epitope in Anaplasma marginale (tick-bornediseases/ rickettsia/gene structure/tandem repeats). Proc. Nati. Acad. Sci., 87, 3220-3224

2. Barbet, A.F.; Blentlinger, R.; Yi, J.; Lundgren, A.M.; Blouin, E.F.; Kocan, K.M. (1999). Comparison of surface proteins of Anaplasma marginale grown in tick cell culture, tick salivary glands, and cattle. Infect. Immun., 67, 102-107.

3. Bastos, C.V.; Vasconcellos, M.M.C.; Ribeiro, M.F.B.; Passos, L.M.F. (2006). Use of refrigeration as a practical means to preserve viability of in vitro-cultured IDE8 cells. Exp. Appl. Acarol. 39, 347-352.

4. Blouin, E.F.; Kocan, K.M. (1998). Morphology and development of Anaplasma marginale (Rickettsiales: Anaplasmataceae) in cultured Ixodes scapularis (Acari: Ixodidae) cells. J. Med. Entomol., 35, 788-797.

5. Blouin, E.F.; Barbet, A.F.; Yi, J.; Kocan, K.M.; Saliki, J.T. (2000). Establishment and characterization of an Oklahoma isolate of Anaplasma marginale in cultured Ixodes scapularis cells. Vet. Parasitol., 87, 301-313.

6. Blouin, E.F.; de la Fuente, J.; Garcia-Garcia, J.C.; Sauer, J.R.; Saliki, J.T.; Kocan, K.M. (2002). Applications of a cell culture system for studying the interaction of Anaplasma marginale with tick cells. Animal Heath Research Reviews, 3, 57-68.

7. Bowie, M.V.; de la Fuente, J.; Kocan, K.M.; Blouin, E.F.; Barbet, A.F. (2002). Conservation of major surface protein 1 genes of Anaplasma marginale during cyclic transmission between ticks and cattle. Gene, 282, 95-102.

8. Gonçalves-Ruiz, P.M.; Passos, L.M.F.; Martins, M.S.; Patarroyo, J.H.S.; Ribeiro, M.F.B. (2002). Antigenic characterization of morphologically distinct Anaplasma marginale isolates using a panel of monoclonal antibodies. Vet. Parasitol., 107, 169-177.

9. Gonçalves-Ruiz, P.M.; Passos, L.M.F.; Ribeiro, M.F.B. (2005). Lack of infectivity of a Brazilian Anaplasma marginale isolate for Boophilus microplus ticks. Vet Parasitol 128, 325-331

10. Kieser, S.T.; Eriks, I.S.; Palmer, G.H. (1990). Cyclic rickettsemia during persistent Anaplasma marginale infection of cattle. Infect Immun., 58, 117-119.

11. Kocan, K.M.; Ewing, S.A.; Hair, J.A.; Barron, S.J. (1984). Demonstration of the inclusion appendage of Anaplasma marginale in nymphal Dermacentor andersoni. Am. J. Vet. Res., 45, 18001807.

12. Kumar, S.; Tamura, K.; Nei, M. (2004). MEGA 3: integrated software for Molecular Evolutionary Genetics Analysis sequence alignment. Brief. Bioinform., 5, 150-163. 
13. Kuttler, K.L.; Winnward, L.D. (1984). Serologic comparisons of four Anaplasma isolates as measured by complement-fixation test. Vet. Microbiol., 9, 181-186.

14. Munderloh, U.G.; Liu, Y.; Wang, M.; Chen, C.; Kurtti, T.J. (1994). Establishment, maintenance and description of cell lines from the tick Ixodes scapularis. J. Parasitol., 80, 533-543.

15. Munderloh, U.G.; Blouin, E.F.; Kocan, K.M.; Ge, N.L.; Edwards, W.L.; Kurtti, T.J. (1996). Establishment of the tick (Acari: Ixodidae) borne cattle pathogen Anaplasma marginale (Rickettsiales: Anaplasmataceae) in tick cell culture. J. Med. Entomol.; 33, 656-664.

16. Ribeiro, M.F.B.; Reis, R. (1981). Exposição natural de bezerros em áreas endêmicas de Anaplasma marginale de Minas Gerais. Arq. Esc. Vet. Univ. Fed. Minas Gerais, 33, 63-66.

17. Ribeiro, M.F.B.; Lima, J.D. (1996). Attempted transmission of Anaplasma marginale by infected Boophilus microplus. Arq. Bras. Med. Vet. Zootec., 48, 397-402.

18. Ribeiro, M.F.B.; Passos, L.M.F.; Guimarães, A.M. (1997). Ultrastruture of Anaplasma marginale with an inclusion appendage, isolated in Minas Gerais, Brazil. Vet. Parasitol., 70, 271-277.

19. Ristic, M.; Carson, C.A. (1977). Methods of immunoprophylaxis against bovine anaplasmosis with emphasis on use of the attenuated
Anaplasma marginale vaccine. In: Miller, L.H.; Pino, J.A.; McKelvey, J.J. (eds) Immunity to blood parasites of animal and man: advances in experimental medicine and biology. New York: Plenum Publishing Corp., 151-188.

20. Smith, R.; Levy, M.G.; Kuhlenschmidt, M.S.; Adams, J.H.; Rzechula, D.G.; Hardt, T.A.; Kocan, K.M. (1986). Isolate of Anaplasma marginale not transmitted by ticks. Am. J. Vet. Res., 47, 127-129.

21. Tebele, N.; McGuire, T.C.; Palmer, G.H. (1991). Induction of protective immunity by using Anaplasma marginale initial body membranes. Infect. Immun., 59, 3199-3204.

22. Wanduragala, L.; Ristic, M. (1993). Anaplasmosis. In: Woldehiwet Z. and Ristic M. (eds) Rickettsial and Chlamydial Diseases of Domestic Animals. Oxford: Pergamon Press, 65-88.

23. Wickwire, K.B.; Kocan, K.M.; Barron, S.J.; Ewing, S.A.; Smith, R.D. (1987). Infectivity of three Anaplasma marginale isolates for Demarcentor andersoni. Am. J. Vet. Res., 48, 96-99.

24. Zweygarth, E.; Josemans, A.I.; Spickett, A.M.; Steyn, H.C.; Putterill, J.; Troskie, P.C.; Mtshali, M.S.; Bell-Sakyi, L.; Shkap, V.; Fish, L.; Kocan, K.M.; Blouin, E.F. (2006). In vitro cultivation of a South African isolate of an Anaplasma sp. in tick cell cultures. Onderstepoort J. Vet. Res., 73, 251-255. 